violence has provoked in Canadian inner cities, reify a decidedly anti-feminist position: that certain women deserve, even invite the violence to which they are subjected. Furthermore, we must find means to counter decidedly anti-feminist public responses to mass/serial murder cases that imply that any poor womanand particularly any Indigenous woman-who stands on an urban street and offers sexual services to passersby in exchange for money or drugs is essentially suicidal and thus shares responsibility for any violence-misogynist, racist, classist, or otherwise- to which she is subjected (178).

Mandy Swygart-Hobaugh Georgia State University

\title{
Holly M. Karibo, Sin City North: Sex, Drugs, and Citizenship in the De- troit-Windsor Borderland (Chapel Hill: University of North Carolina Press, 2015). 226 pp. Paperback $\$ 29.95$.
}

This short and impressively well-written book explores sex, drugs, and citizenship in the Detroit-Windsor borderland between the 1920s and 1967 (the year of the Detroit race riot). Situated in the strong tradition of borderlands scholarship, the book takes as its focus the less studied borderland between the United States and Canada. Karibo argues that borderlands have often been conceived as "meeting places" where people from different cultures came together. The Canada/US border is marked more by similarity than difference, and yet the border still matters: while this border was crossed frequently for trade, work and pleasure it was also upheld against the vice that was perceived to exist on both sides.

The book starts with the opening of the Ambassador Bridge between the two countries in 1929. The bridge and tunnel eliminated the necessity for the short ferry rides that had previously taken people from Windsor to Detroit and vice versa. Karibo explains that the bridge (which could handle as many as 4,000 cars/hour) exemplified the growing connections between the two countries for trade and travel, but that the bridge's well-regulated border inspection process also reified a border that had once been policed fairly informally. I was surprised to learn exactly how many people in the Canadian border cities worked in Michigan: Karibo reveals that by $1927,15,000$ of the 25,334 employed residents of the Canadian border cities actually worked on the other side of the border (19).

The different liquor laws in the two countries helped to create the region's illicit economies. Ontario's experiment with prohibition was relatively short-lived and the province never forbad the production of alcohol. As a result, the DetroitWindsor border (or the Detroit-Windsor funnel) became a major site for smuggling liquor from Canada to the US. After Ontario repealed prohibition in 1927 and 
opened the Liquor Control Board of Ontario outlets for retail sale, many Detroiters began crossing the border to drink legally. Indeed, during the American national holiday that year, cars were backed up at the Windsor Ferry docks for ten miles (31). Holiday operators in Windsor urged Americans to "Come to Canada and Enjoy Life." But others were less enthusiastic about drunken tourists and the reputation Canada was gaining as a centre of the illicit alcohol traffic. In Detroit, many African-Americans migrated to the city search of opportunity, but found few opportunities open to them. As a result, they frequently sought employment in the illicit alcohol trade and prostitution. The growth of the illicit economy and the accompanying rise in gun violence gained Detroit a reputation as the "blackest hole of crime and vice in the United States" (36). The growth in crime associated with Prohibition eventually led to its repeal in 1933.

World War II led to an economic boom in both cities as empty factories were converted to war production. While finding work was easy, finding housing was trickier and infrastructure in both cities groaned under the strain of many new migrants. The boom years (which lasted through to the late 1940s) brought more southerners, both African-American and white, to Detroit; while many people from mining districts elsewhere in Canada relocated to Windsor. Race relations in Detroit grew tense: in 1943 a race riot left twenty-five African-Americans and nine whites dead. Even so, cross-border tourism flourished, especially once the war ended. In Windsor, some businesses relied almost exclusively on American tourists for their earnings, while Canadians crossed the border for the amenities offered by the much larger city. Detroit Red Wings games were a popular draw, as was the theatre and shopping. City boosters celebrated the cross border tourism and some speculated that events like the "Freedom Festival," a five-day celebration spanning the two countries' national holidays, would usher in a new era of peace and cooperation (51-52).

But the borderland also continued to be a site of vice. Sex tourists crossed the border both ways, partly because crossing the border spoke of danger and adventure, but also because greater anonymity was possible outside of one's home community. The much later bar opening hours in Detroit and the ban on Sunday entertainments in Ontario led many Windsorites, in particular, to cross the border in search of fun and pleasure. Detroit had a thriving sex industry. In the years after World War II, sex workers in Detroit were increasingly African-American-a fact that reflected the limited economic opportunities available to them in a racially tense city. By comparison, nearly half the sex workers in Windsor were French-Canadian, a legacy of a crack-down on vice in Montreal in 1946. The sex industry in Windsor was also segregated: all of the customers arrested in the fifteen years after World War II were listed as "white" —Karibo describes American sex tourism to Windsor as a form of "white flight" (65). In general, either for sex or entertainment, few African-Americans were drawn to Windsor where they were frequently turned away from bars and restaurants on account of their race, an important reminder that de- 
spite its reputation for tolerance, Canada could be a deeply racist place.

Another chapter explores drug use and the drug trade in the two cities. Karibo thoughtfully discusses the pleasures as well as the dangers of using heroin, the drug of choice in both cities. While Windsor had a very small number of resident users, many Canadian users passed through the city in search of drugs. In Detroit, the vast majority of people arrested for drug offences were African-American, perhaps reflecting the policing of drug use in their communities, but perhaps also because the illicit economy offered a chance to get ahead for African-American youth, although even these gains were often elusive; the real profits were made by the white higher-ups. By the mid-1950s, black residents regularly complained about the brutality that they faced from police. Karibo underlines the shocking lack of diversity on the Detroit police force: while the city had a large African-American population, less than $1 \%$ of Detroit police officers were black (82).

Karibo argues that moral reformers in Detroit and Windsor focused on three issues in the post-war years: transience, juvenile delinquency, and urban housing renewal. All of these issues were tied to race and citizenship. There was considerable fear of transient men, and concern about transient young women, especially the fear that they might be lured into prostitution. Carnival workers caused particular alarm. In Detroit, there was ongoing concern about the southerners, both white and African-American, who flooded into the city in search of opportunity. Detroit was particularly active in the field of urban renewal in postwar years, tearing down so-called "blighted neighborhoods" that were perceived to be centres of vice and building new housing. These projects often replaced working-class housing with middle or upper-class housing, making it even more difficult for working-class residents to find a place to live. Many Detroit citizens would come to know urban renewal as "negro removal." There was also considerable alarm about juvenile delinquency and especially the moral danger posed by children growing up with single-mothers. A final chapter explores Senate Committees established in both the US and Canada to investigate drug trade: these committees made remarkably similar recommendations around the need for harsher sentences and more enforcement, showing once again the similarities between the two countries.

Throughout the book, Karibo emphasizes the extent to which economic opportunities began to decline in both cities by as early as the 1940s. This provides an interesting corrective to the general narrative of a much longer period of postwar prosperity. This is such an interesting point that I wish that she had made it even more central to her analysis, and included more details about unemployment and work opportunities. In general, I wish that there had been more attention to chronology - for the two decades that followed World War II Karibo moves back and forth in time, and I wanted a greater sense of change over time. I also wondered if more could have been said about the images/stereotypes of these cities within their respective national contexts and if this could have added further depth to the borderlands analysis? Finally, Karibo rarely connects her work to that of other his- 
torians. In my view, this helps her story shine through and will make this an excellent book for undergraduate course adoptions. But other readers will undoubtedly want more focus on the larger historiography.

Catherine Carstairs

University of Guelph

\begin{abstract}
Barry Wright, Eric Tucker, and Susan Binnie, eds., Security, Dissent, and the Limits of Toleration in War and Peace, 1914-1939, Canadian State Trials, vol. IV (Toronto: University of Toronto Press, 2015). XV+517pp. Hardcover $\$ 50.00$.
\end{abstract}

This important volume of eleven essays and three appendices carries the extraordinary Canadian State Trials (CST) project resolutely on to the terrain of Hobsbawm's Age of Extremes, the Short Twentieth Century. This collection is the fourth in the series that commenced with Law, Politics and Security Measures, 1608-1837 (1996) and was followed by Rebellion and Invasion in the Canadas, 1837-1839 (2002) and Political Trials and Security Measures, 1840-1914 (2009). The late F. Murray Greenwood began the path-breaking project in the 1990s and co-edited the first two volumes before his death in December 2000. His co-editor on those volumes, Barry Wright, has continued with co-editors Susan Binnie on volumes III and IV and Eric Tucker on volume IV.

The rationale for the series, and a fascinating account of its eighteenth and nineteenth-century British predecessors, appeared in the first volume:

The way is open to return to the tradition of the libertarian state trial editors, where a critical eye may be cast at the contradictions between repressive or partisan practices and claims made about the impartiality of the law ... Security cases highlight an ongoing tension between the rule of law and the discretionary exercise of executive measures and reveal something about the role of law in the exercise of power (CST, I, 9).

Wright has consistently maintained the breadth of interpretation established in the wide selection of material for inclusion under the rubric "state trials." He has also continued the valuable addition of archival explanation and commentary Judi Cumming), as well as a selection of major legal documents. Indeed, in the case of this volume, such additional materials are extended to include an analysis of the significant problems faced by researchers owing to Canada's sadly out-dated Access to Information legislation (Patricia I. McMahon).

Following an excellent introduction by the editors, the essays fall into three unacknowledged groupings: four on the crises of World War I; three related to the 